IZA DP No. 7201

Regulation, Trust, and Cronyism in Middle Eastern Societies: The Simple Economics of 'Wasta'

Andy Barnett

Bruce Yandle

George Naufal

February 2013 


\title{
Regulation, Trust, and Cronyism in Middle Eastern Societies: The Simple Economics of 'Wasta'
}

\author{
Andy Barnett \\ Auburn University \\ Bruce Yandle \\ Clemson University \\ George Naufal \\ American University of Sharjah \\ and IZA \\ Discussion Paper No. 7201 \\ February 2013 \\ IZA \\ P.O. Box 7240 \\ 53072 Bonn \\ Germany \\ Phone: +49-228-3894-0 \\ Fax: +49-228-3894-180 \\ E-mail: iza@iza.org
}

Any opinions expressed here are those of the author(s) and not those of IZA. Research published in this series may include views on policy, but the institute itself takes no institutional policy positions. The IZA research network is committed to the IZA Guiding Principles of Research Integrity.

The Institute for the Study of Labor (IZA) in Bonn is a local and virtual international research center and a place of communication between science, politics and business. IZA is an independent nonprofit organization supported by Deutsche Post Foundation. The center is associated with the University of Bonn and offers a stimulating research environment through its international network, workshops and conferences, data service, project support, research visits and doctoral program. IZA engages in (i) original and internationally competitive research in all fields of labor economics, (ii) development of policy concepts, and (iii) dissemination of research results and concepts to the interested public.

IZA Discussion Papers often represent preliminary work and are circulated to encourage discussion. Citation of such a paper should account for its provisional character. A revised version may be available directly from the author. 
IZA Discussion Paper No. 7201

February 2013

\section{ABSTRACT \\ Regulation, Trust, and Cronyism in Middle Eastern Societies: The Simple Economics of 'Wasta'}

Despite being a fixture of everyday life in the Arab world, wasta, which may be thought of as special influence by members of the same group or tribe, has received little attention from social scientists. Our casual empiricism suggests that wasta is an important determinant of how economic activities are organized and resources are allocated in Middle Eastern societies, yet economists, even those who specialize in work related to the Middle East, have not addressed the issue of wasta. With this paper we provide a modest beginning to filling that void. Specifically, we use the history of wasta, Hayek's concept of extended order and Coase's work on the nature of the firm to draw inferences regarding the existence of wasta and its persistence in Arab societies.

JEL Classification: D21, K20, N45

Keywords: $\quad$ cronyism, wasta, firm, Hayek, Coase, Middle East

Corresponding author:

George Naufal

American University of Sharjah

School of Business and Management

P.O. Box 26666

Sharjah

United Arab Emirates

E-mail: gnaufal@aus.edu 


\section{Introduction}

For those who work and live in Middle Eastern societies, "wasta," which may be thought of as special influence enjoyed by members of the same group or tribe, is an ever-present part of life. It is deeply embedded in the fabric of these societies and visible in everything from the way in which governments interact with businesses to the way in which public policy is formulated. The use of wasta is common in job search, in procuring a driver's license, gaining university admission, getting a business license, and a host of other everyday tasks.

Wasta is an Arabic term that refers to an implicit social contract, typically within a tribal group, which obliges those within the group to provide assistance (favorable treatment) to others within the group. Members of the group have a largely unqualified obligation to provide assistance when asked, and those who ask for assistance have no obligation to provide direct compensation for assistance provided.

One is said to "have wasta" when those from whom one can request assistance are in positions of power that make it possible for them to grant the requested assistance. Those who have wasta can jump the queue in acquiring public services while those who do not will struggle through the "normal" bureaucratic process. Those with wasta get job interviews and jobs, while

those who do not suffer through calls that are not returned and letters that go unanswered. Those with wasta get favorable rulings from agencies and courts while those who do not often wade through red tape in processes that are not well defined and where outcomes are often unpredictable. Those who have wasta get government contracts and are the beneficiaries of government rules that limit competition, while those who do not find it difficult to enter markets. In short, wasta helps those who have it to navigate bureaucracy or gain favorable treatment in business and government. 
While wasta can be useful for those who wish to bypass the transaction costs of burdensome bureaucratic procedures or who might be unsuccessful when issues are decided based on merit, it has an obvious dark side, at least in the eyes of those who favor and are accustomed to merit-based transactions or “equal opportunity.” Wasta can be viewed as a source of nepotism, cronyism and corruption generally. It can be seen, especially by those who do not have wasta, as a means to gain what seems an undeserved advantage or as a mechanism that yields decisions based on connections instead of merit as perceived by the one who is left out in the cold.

Although we cannot identify a time period when wasta first came into general use, it is clear that variations on wasta have been the norm in most Arab societies for centuries. ${ }^{1}$ Certainly, wasta-like practices have existed in other societies. Indeed, we hold the view that such practices are an integral part of lengthy social processes that generate order within and across all societies. We observe that in most developed countries such practices have fallen into disrepute, and in many these practices have been banned. That is not the case today in Arab societies.

Our conjecture is that wasta, like any long-standing social custom or institution, evolved in Arab societies because, at some point, it was generally perceived as a social construct that provided better solutions to a set of social problems and resource allocation issues than could be achieved by alternative institutional arrangements. It might exist today because it is still generally viewed as efficiency enhancing or, as seems more likely, it could persist as a hangover from a time when it was efficiency enhancing. ${ }^{2}$

\footnotetext{
${ }^{1}$ Wasta can be traced to as far back as the $14^{\text {th }}$ century. Ibn Khaldun points to the importance of connection with the ruler in determining one's profit (Spengler, 1964).

${ }^{2}$ As noted by an anonymous referee, we would expect those who are beneficiaries of wasta to resist changes even when it is clear that wasta is no longer efficiency enhancing. Others, again as pointed out by a referee, my resist changes because wasta is perceived as preserving the interests of a tribal group, its heritage and its customs, and this may be viewed as more important than the wealth enhancing benefits of alternative institutional arrangements.
} 
In this paper we address two specific questions related to the general acceptance of wasta in modern Arab societies. First, what motivates the existence of wasta in the first place? Second, under what circumstances does wasta persist as an accepted social practice? In other words, we attempt to shed light on the social function performed by wasta. What does wasta offer and why does it persist? We focus on the social dynamics that have led to wasta practices becoming a Middle Eastern norm, while those same practices have generally come to be viewed as socially unacceptable or even illegal in Western societies.

We begin in section II with a brief review of the existing literature on wasta. In section III we discuss historical background and how the meaning and use of wasta has evolved over time. We present a simple theory of wasta that focuses on transaction costs and opportunity cost in section IV, and section V contains our concluding comments.

\section{Literature Review}

As best we can determine, economists have not addressed the role of wasta, and the literature on wasta in other social sciences and business is small and largely anecdotal. For example, Alrabaa (2007), a journalist, provides examples of individuals who used wasta to remove parking fines and change grades on university exams. Another journalist, Al-Elwani (2009), relates stories in which wasta was used to get reduced apartment rent, procure a driving license and receive favorable treatment in provision of medical care.

Of course, it is difficult to analyze what we cannot define, and defining wasta is a challenge. It is tempting to adopt the position of U.S. Supreme Court Justice Potter Steward who in a case dealing with "hardcore pornography" noted that while he could not define hard-core pornography, "I know when I see it..." On the other hand, we find both in the existing literature and in our own experience and conversations, that it is sometimes difficult to "know wasta when 
we see it." The distinction between personal favors or bribes, on the one hand, and wasta on the other is not always clear.

Arguably, the source that comes closest to providing a definition is Cunningham and Sarayrah (1993) (both political scientists). They note that the word wasta comes from the word waseet which refers to a middleman. The middleman's main function is to act as an intermediary for two parties. According to Cunningham and Sarayrah, the type of mediation used defines the type of wasta provided. Further, the authors argue that the use of wasta is not strictly limited to the family (tribal) network but can sometimes include close friends and even acquaintances.

Cunningham and Sarayrah (1993) further suggest that wasta is not limited to a particular sector of human interaction. It exits in government, academia, health services and business. Ezzedeen and Sweircz (2001), human resource management professors, find that as many as 65\% of employees in the second largest mobile telecommunications provider in Lebanon were hired through wasta. More recently, Loewe et al. (2006) examine the effects of wasta on the business climate in Jordan. They conclude that wasta contributes to the mediocre quality of the Jordanian business climate by exacerbating the complexity of administrative procedures and adding to unfairness in administrative decisions.

Izraeli (1997), an ethicist, addresses the questionable ethics of wasta. Mohammad and Hamdy (2008, p. 1), management professors, note that despite being considered immoral by western standards, wasta is widely practiced throughout the Arab world. They argue that unqualified candidates obtaining jobs solely on the basis of influence or connections has created an environment that continues to feed frustration among qualified and well skilled individuals.

Much of the discussion of wasta in the current literature characterizes the practice as nepotism or corruption (Loewe et al. 2006 and Mohamed and Hamdy, 2008). However, wasta is not seen, at least not uniformly, as a form of corruption within most Middle Eastern societies. It 
is embedded in the social fabric of Middle Eastern society and is practiced openly, without apparent shame, remorse or guilt. Acts seen as “corruption” are typically subject to criminal penalties, even in the Middle East, while instead of being subject to criminal prosecution or social ostracism, wasta is celebrated. Indeed, wasta is often a source of pride and prestige both for the waseet and for those who gain favorable treatment via wasta. Further, nepotism, bribery and other forms of corruption are typically characterized by a quid pro quo. Direct reciprocity is not a requirement for wasta. Instead, reciprocity comes in the form of an implicit obligation to provide aid when requested by other members of a specific social network, often a tribal group. As a consequence, wasta acts as an invisible hand that facilitates individuals engaged in complex exchanges within a social network. In this regard, wasta has many of the characteristics of a multi-stage game. ${ }^{3}$

Finally, some literature notes that, while wasta is prevalent in Arab societies, wasta-like practices also occur elsewhere. Izraeli (1997) notes that in Israel protektzia is similar to wasta. Hutchings and Weir (2006), management professors, observe that similar practices in China are referred to as guanxi. As previously noted, we are inclined to argue that wasta-like customs exist in every settled society to one degree or another and are rooted in the evolution of humans and their communities. ${ }^{4}$ Along these lines, we propose that wasta-influenced transactions gradually dissipate as tribe members become more engaged with the broader impersonal market. However,

\footnotetext{
${ }^{3}$ Bellow (2003), an editor and author, argues that wasta in itself is neither good nor bad; hence the labeling of something as good wasta or bad wasta is simply a cultural construct. In a modern context, wasta is almost always intercessory wasta. Intercessory wasta refers to getting a job done solely based on a person's influence with others. The link can be established with someone within a family (nepotism) or outside, such as through a circle of friends or acquaintances.

${ }^{4}$ In Darwinian Politics, Rubin (2002) focuses on deep evolutionary forces that equipped human communities with survival traits. Kin selection is the foundation for small group survival in a world of competing tribes. As Rubin puts it (23): "To the extent that members of the groups are related, this mechanism comes into play to explain cooperation. Altruism toward kin is dependent on costs and benefits: as the cost to the altruist decreases or the benefit to the recipient increases, and as relatedness increases, such altruism becomes more likely." Rubin goes on (24) to point out that kin-based altruism (wasta) can be reinforced by inheritance mechanism, a characteristic seen often in highly cooperative social insects.
} 
the rate at which dissipation occurs relates directly to the availability of other trust- and ordergenerating mechanisms that can replace tribal wasta. ${ }^{5}$ We also note that less noticeable wastalike behavior is widespread. Put another way, individuals in open and free societies form and choose groups and organizations with which they wish to become engaged. In the West, organizations such as Rotary International, Kiwanis, social fraternities, and even individual churches within particular denominations may be seen as wasta-like institutions that reduce the cost of communicating and transacting where complex cultural norms are involved. ${ }^{6}$

\section{Wasta in Historical Perspective}

The evolution of wasta as a behavioral norm in Middle Eastern societies raises some rather interesting questions. Why did this social custom evolve specifically in Middle Eastern societies? In other words, what useful social function does wasta provide in such societies? Second, why does wasta persist as a dominant social custom in Middle Eastern societies, while the practices encompassed by wasta have fallen into disrepute in most modern Western societies? As a starting

\footnotetext{
${ }^{5}$ Antoun $(2000,444)$ addresses tribal ordering systems as trust-forming institutions. He goes so far as to say that (444): "The problem for all societies in the modern world is how to create public trust to accomplish social goals while making some accommodation for the rights of the individual." We view the tribal unit as a provider and guardian of trust. This means that there must be accountability, enforcement of tribal rules, and protection of tribal rewards, of which wasta is just one.

${ }^{6}$ Lipford and Yandle (2009) argue that volunteer activity, where individuals in the United States donate time to various civic, churches, and community activities, will be higher when the group receiving the donated service shares characteristics with those who are donating. The Lipford-Yandle empirical work supports the theoretical argument. The argument turns on the notion of interdependent utility functions and the ability of the donors to "read" the recipients' evaluation of the donated effort. Put another way, those donating seek to provide something of value as seen in the eyes of the recipient. Shared cultural norms reduce the cost of evaluating activities. The same argument can be applied to tribes that share a common history as well as common ancestors, customs and traditions. Allocating responsibilities, rewards, and punishments can be done more efficiently within the tribe, which lowers the cost of tribal survival. Common culture, language, history, and hierarchy are specialized assets that enter the tribe's production function.
} 
point to address these questions, it is perhaps helpful to address the historical evolution of wasta in Arab societies.

\section{The Evolution of Wasta in Tribal Society}

Traditionally, wasta was used as a means of mediation between families to resolve conflict. The head of the family, tribe or clan acted as the waseet (middleman) to mediate and adjudicate within the tribal group and to negotiate points of conflict with other tribal groups. In so doing, the wasta helped solidify and maintain the unity, integrity, and status of the tribal group within the broader society (Al-Ramahi, 2008).

In time, wasta evolved into a means of intercession. Emphasis shifted from preserving and enhancing the status of the tribe to furthering the interests of the individuals who comprise the tribal group. This movement from collective to individual benefit seems to be a relatively modern innovation that occurred as globalization and greater competitiveness in the work environment imposed new stresses on Arab societies (Bellow, 2003) The change may also be seen as a move in the direction of wasta's slow disappearance as a dominant social mechanism. ${ }^{7}$

As wasta evolved from a mechanism for mediation to one that is intercessory, the mechanics of wasta also evolved. Specifically, the role of the waseet was diminished. Individuals with acquaintances who had the ability to provide wasta could go directly to those individuals, avoiding the middleman. Presumably, transaction costs fell in the process. It is important to note that despite the evolution of wasta into a means to further individual interests, the welfare of the family and tribe, as opposed to personal interests, continued to be a driving force in the practice

\footnotetext{
${ }^{7}$ For the United Arab Emirates (UAE) and other oil-rich Gulf Cooperation Council (GCC) countries "the effect of wealth, particularly its recent and sudden arrival, its distribution ... [and] the influence of tribe, family, party, sect loyalty all [had] a great bearing upon productivity and the mentality and attitudes around work ethics" (Meles 2007, 16).
} 
of wasta, though with the transition to intercessory wasta tribal welfare was promoted in a more subtle way.

Some of the differences between “old wasta” and "new wasta” are important. With old wasta, the tribal leader sought to gain an advantage on behalf of the tribal group so that wasta worked from top down. New wasta, while still yielding advantage for the tribal group, works from bottom up. Moreover, with old wasta tribal elders and leaders gained status and authority via their role as middlemen. This source of status and authority is largely lost with new wasta. ${ }^{8}$

\section{The Role of the Colonial Period and the Modern Nation State}

The practice of wasta in the Middle East has its roots in a tribal system of social organization that has characterized Arab society for millennia (Al-Ramahi, 2008). The extended family unit was, and still is, the bedrock of the organizational context for wasta. Indeed, we argue that wasta persists in Arab societies largely because of the tribal structure of those societies.

This tribal structure, in turn, has been influenced by the colonial history of the Middle East. Most of the Middle East has a long history of colonial rule. In ancient times the Greeks and Romans ruled much of the region. The Mongol empire also reached into parts of the Middle East in its time. In more modern times, the Ottomans dominated the region from the early sixteenth century through the post-WWI period, when the Ottomans were defeated and control of most of the Middle East was ceded, by international agreement and in 1922 by the League of

\footnotetext{
${ }^{8}$ It is worth to note that, while the term wasta along with some of the social customs surrounding the practice of wasta is unique to Arab societies, the essence of the opportunistic behaviors that characterize wasta are not unique. Bellow (2003), for example, provides insight into the evolution of opportunistic behavior in other societies. Specifically, Bellow addresses the historical evolution of nepotism in the U.S and argues that in modern American society nepotism works like an invisible hand creating opportunities for profit. Nepotism, according to Bellow, is a productive social mechanism through which social or cultural values are passed to future generations (Bellow, 2003).
} 
Nations, to the French and the British. The end of WWI did not, however, mark the beginning British and French colonial influence in the Middle East. Beginning in the late eighteenth century, declining power of the Ottomans and increasing assertiveness of European economic and military power produced a series of concessions by Ottoman rulers that effectively, but not literally, established Great Britain and France as colonial powers in large parts of the Middle East. ${ }^{9}$ The region was not fully carved into independent nation states until the decades following World War II.

Control of the indigenous population of the region by colonial powers, particularly during the period of Ottoman and European rule, was facilitated by exploiting the tribal nature of Arab society. Specifically, colonial powers became allied with local agents (tribes and influential families) who were rewarded for their loyalty with land grants and local political power (ElGhonemy, 1998). These practices, in turn, facilitated a patronage system, which reinforced wasta as a cultural norm.

The economic incentives that reinforced patronage and wasta were significant. Bellow (2003) observes that tribal groups who were allied with colonial powers were rewarded with tax exemptions, special grants and official positions that provided opportunities to extract economic rents from other inhabitants. Hence, the tribe, already an important fixture in Arab society, became an even more powerful engine of social mobility. Colonial rule provided a format for political advancement and a mechanism for those who climbed the political ladder to assist relatives in following their footsteps. In short, the social stratification that occurred during this

\footnotetext{
${ }^{9}$ For a detailed discussion of the complexity and intrigue that characterized the colonial period in the Middle East see Cleveland (2004), pp. 37-274.
} 
period determined the kind and quality of assistance that could be provided to kin within a network, and hence the power, wealth and prestige of the tribal group. ${ }^{10}$

The history of the Arab world, both before and during colonial rule, is a history of families and tribes. Nation states by contrast are a recent innovation in the Arab world. Most modern Arab countries were formed in the last 80 years. ${ }^{11}$ Further, in many cases the geographic boundaries of these states were delineated by departing colonial powers based on their political needs and concerns. In short, they were not generally formed to meet the needs and interest of the local inhabitants.

Where nation states evolve more or less naturally, they tend to include inhabitants who share a sense of ethnic, historical and cultural identity. Given the tribal nature of Arab society, this would suggest national boundaries that would conform to boundaries of traditional tribal areas and to historical tribal alliances. While the departing French and British no doubt assigned weight to these factors, they also had other objectives. As a result, some of the nation states they created were characterized by heterogeneous populations with little sense of shared goals. Many of these countries are still in the process of developing national identity and national allegiance. As a consequence, individuals within these states are likely to identify more strongly with their tribal group than with their nation state.

The implications for wasta of weak national identity and strong tribal ties seem obvious. Where tribal ties dominate national interests, a social convention (like wasta) that favors the interests of tribal members above national interests is likely to be viewed as both logical and virtuous. By corollary, a setting in which inhabitants have strong national identity is likely to

\footnotetext{
${ }^{10}$ El-Ghonemy (1998) argues that the colonial period set in place a set of incentives that allowed Middle Eastern tribes to operate much like trade unions, where the interests of members within the union reduce risks and extract rents by virtue of their membership in the union.

${ }^{11}$ http://en.wikipedia.org/wiki/List_of_sovereign_states_by_formation_date. Retrieved on December 17, 2011.
} 
yield a value system that assigns virtue to actions that further the national interest against other interests. ${ }^{12}$ For example, an Englishman or American who shows favoritism for his country or his compatriots is likely to be applauded as patriotic. Indeed, during times of conflict those who place other interests over those of their country risk being shot as traitors.

\section{A Simple Theory of Wasta}

While the politics of colonial rule may have influenced the use of wasta in Arab societies, it does not answer our fundamental question. Specifically, how did tribal customs and traditions evolve? And why would wasta be one of the dominant remaining features of tribal dominance? Hayek (1988) takes a long view of how order, and ultimately what he terms civilization, evolved and how survival in the modern setting required human beings to act against their deeply ingrained instincts for self-preservation. As Hayek $(1988,12)$ explains:

"Mankind achieved civilization by developing and learning to follow rules (first in territorial tribes and then over broader reaches) that often forbade him to do what his instincts demanded, and no longer depended on a common perception of events. These rules, in effect constituting a new and different morality, and to which I would indeed prefer to confine the term 'morality', suppress or restrain the 'natural morality', i.e., those instincts that welded together the small group and secured cooperation within it at the cost of hindering or blocking its expansion.”

Here we see a different take on morality of the tribe and a new morality of what Hayek calls the extended order. Wasta is a feature of tribal morality that does not seem to fit the extended order.

Hayek’s observation $(1988,12)$ also relates to the tension between the old (wasta) morality and the new, modern, (wasta) morality when he explains what happens when transacting in the extended order. Wasta serves to weld together the small tribe, but carried an opportunity cost that increases with exposure to the extended order.

\footnotetext{
${ }^{12}$ For examples, soldiers who "sacrifice their lives for their country" are typically viewed as being among a country's most honored and admired citizens.
} 
The Theoretical and Empirical Questions Arise: Why Wasta and When Will Wasta Disappear?

Consider the tribe as a firm. In his seminal piece on the nature of the firm, R.H. Coase (1937) offers an economic explanation for the existence of the firm. Transaction cost lies at the crux of the explanation. The cost of using the market for allocating resources is the issue. If we substitute tribe for firm, we may have a similar argument. The tribe continues to operate as an effective wealth-creating and -conserving entity so long as the transaction cost avoided by tribal governance is greater than the gains from trade foregone. Tribal disintegration would open the collective to individual gains from trade, but within the context of new non-tribal firms and entities. Wasta denotes the boundaries of the tribal firm. But there are many conceptual wasta margins. For example, wasta applied to marriage; wasta applied to buying and selling; wasta is predicted to disappear at different margins, based on the burden of maintaining it.

Wasta is discrimination in favor of the tribe. It is costly, but it can also be beneficial to those who practice it. Becker's $(1971,6)$ analysis of discrimination is relevant here. Where the discriminating group is large relative to the rest, the cost of discrimination (wasta) can be small, which is to say that gains from open trade are apt to be small in total. But where the group discriminated against is larger, more diverse, and able to provide the benefits of specialization, then the cost to the discriminating group rises. In this sense, wasta costs rise as the tribe becomes more engaged in the extended order and less reliant on the specialized cultural traits that are necessary to generate trust and efficient contracting.

Why Wasta and When Will Wasta Disappear? Wasta as Insurance

Wasta may also be seen as a form of social insurance. Prior to the second half of the twentieth century (before large oil and gas exports) many Arab societies were characterized by 
high levels of personal and corporate risks. Arab countries in the Persian Gulf and parts of North Africa, for example, were sparsely populated by nomadic herders and traders who had few easily transferred assets. The desert climate was harsh, raiding occurred between tribal groups, and there were few formal avenues for conflict resolution. In short, life was a risky business and wasta provided mutual insurance that facilitated survival in such harsh environments.

With wasta, each member in need could ask for, and reasonably expect, assistance from other members of the group. Each member also had a never expiring obligation to provide assistance when asked. This obligation constituted the premium paid for the right to request assistance.

Wasta has some rather obvious advantages as an insurance mechanism in tribal societies. Where the insurance is mutual within a tribal group each member of the group would generally have more accurate information about other members of the group than would outside insurance providers. Hence, information asymmetry may be less of an issue with wasta than with more conventional forms of insurance. Moral hazard, while still present, may also be less of an issue when insurance is internal to a tribal group. As with any insurance scheme, wasta flourishes so long as the total premiums paid exceed the claims made on the premium pool. Survival of the insurance scheme could be better assured when wasta was facilitated by tribal managers. Breakdown of a tribal monitoring mechanism predicts the end of wasta.

\section{Simple Analytics of the Practice of Wasta}

Following Coase and Williamson (1985), we describe wasta as a preference for production within the boundaries of the tribe (firm). In more primitive times when migratory tribes had only limited engagement with other tribes, production and exchange within the tribe, broadly interpreted, was the dominant social institution. Most likely, surviving tribes were large 
enough and diverse enough to yield ultimate economies of scale in the crude production of lifesustaining goods and services. Tribes were large enough for specialization and intra-tribal trade to emerge. Marriage within the tribe preserved tribal wealth and sustained tribal customs, traditions, and lessons from the past. Common culture, language, history, and hierarchy were specialized assets that entered the tribe's production function. These practices and habits of the heart became bundled in wasta. When evaluated in isolation from the rest of the world, wasta was efficiency enhancing and therefore life and wealth preserving. But the cost of wasta habits increased as technologies changed within the tribe and within the rest of the world.

We now use a distilled version of Williamson's $(1985,9)$ analysis of the decision to produce within the firm (tribe) versus securing goods and services from the market (rest of the world), as a simple way to describe different wasta equilibrium conditions. In Figure 1, we show marginal benefit (MB) and marginal cost (MC) relationships for extending the use of wasta across transactions involving tribal activity. The range of wasta coverage from zero to 100 percent is shown on the horizontal axis. Underlying the marginal relationships are technologies, size and scope of tribe and external groups and institutions for engendering trust and contract enforcement. Wasta is obviously a trust/enforcement device for each category of activity where it is applied.

$\mathrm{MB}_{1}$ and $\mathrm{MC}_{1}$ in Panel $\mathrm{A}$ are the initial conditions. $\mathrm{MB}_{1}$ registers the marginal benefits of within-tribe wasta. $\mathrm{MC}_{1}$ represents the opportunity lost from engagement with extra-tribal parties. As indicated by the fact that there is no intersection point, $100 \%$ of tribal activities are affected by wasta. There is no opportunity cost associated with showing tribal preference for all activities. In Panel B, we describe a situation where the rest of the world has adopted new technologies or discovered greater economies of scale for producing a good or service demanded by the tribe being analyzed. There is an intersection point that implies a zone where the marginal 
benefit of wasta is less than the marginal cost of using wasta. If wasta continues to be applied in that zone of activity, potential tribal wealth will decline. Panel C shows a more extreme version of the picture in Panel B. Given the intersection point, if wasta continues to be applied across 100 percent of the wasta potential, wealth loss becomes larger.

The simple analytics suggest that tribes can certainly isolate themselves from the rest of the world and maintain wasta traditions over a large part of community life. In the United States, we observe this in Amish, Hutterite, Mennonite, and Orthodox Jewish communities, as well as in Native American tribes and aboriginal communities in other locations. Generally speaking, the extensive use of wasta-like customs produces a wealth effect that can be observed by a visitor who is accustomed to measuring wealth in what might be called the ways of the Western world. The underlying analysis shown in Figure 1 suggests that, at some margin of cost, some activities previously covered by wasta will join Hayek’s extended order. This does not mean that all wastacovered activities will do so. The analysis also suggests that reversals can occur; that some things released to the extended order can be recalled when the cost of wasta falls.

The notion that there are limits to net gains from suppressing open market engagement in favor of tribal transactions is captured analytically in a model developed by Oliver Williamson (1985). His argument focused on the use of specialized assets internal to the firm (tribe) that, depending on the relative net benefits involved could favor internal procurement as compared with market contracting. Williamson's analysis also takes account of differences in the cost of obtaining a good or service from the external market versus the cost of internal production. High within-tribe specialization can be so beneficial that favoring the tribe (wasta) more than offsets any gains from market contracting. If the gains from specialization fall and/or the cost of obtaining services from the market fall, then within-tribe specialization declines, and with it the scope of wasta. 


\section{Legal Suppression of Wasta}

We turn now to make one final point. How might we explain legislation, such as the U.S. Equal Rights Amendment and other laws that seek to suppress favoritism based on race, religion, or national origin? Put another way, when might it be collectively efficient for a society to outlaw the extensive use of wasta? Our simple analysis has addressed decisions within the tribe. If we visualize political space filled by competing tribes where each tribe is struggling to open its borders and reduce wasta, we can imagine how a multi-tribal government might emerge for the purpose of reducing transaction costs across tribes. Something like the commerce clause in the U.S. Constitution comes to mind. Efforts to suppress barriers to trade may be driven collectively by tribal leaders who recognize that their wealth will increase if transaction space is broadened.

\section{Conclusion}

Wasta is a fixture of everyday life in the Middle East. Indeed, as Meles $(2007,16)$ notes "Wasta [now] has become a right and expectation" in Arab societies. In this paper we address the reasons for the evolution of wasta and posit rationales for its use in these societies. With a better understanding of why this particular mechanism has evolved and persists, perhaps future research can help us better understand its consequences. Other more creative and insightful investigators can find more and better explanations for the existence of wasta. Our hope is that others will add rigor and specificity to our modest beginning, and in doing so, bring wasta out of the shadows of academic discourse. 


\section{References}

Al-Elwani, Jasim. (2009). The Evolution of Wasta: Extreme or Mainstream? Kuwaittimes $\begin{array}{llll}\text { retrieved } \quad \text { May } & 2010\end{array}$ http://www.kuwaittimes.net/read_news.php?newsid=MTAzNDY0NTIyMQ==

Alrabaa, Sami. (2007) Wasta's Vicious Circle. Kuwaittimes, retrieved on May 23, 2010 http://www.encyclopedia.com/doc/1G1-168895561.html

Al-Ramahi, Aseel. (2008). Wasta in Jordan: A Distinct Feature of (and Benefits for) Middle Eastern Society. Arab Law Quarterly, 22: 35 - 62

Antoun, Robert T. (2000). Civil Society, Tribal Process, and Change in Jordan: An Anthropological View. International Journal of Middle East Studies 4(32): 441-463.

Becker, G. (1971). The Economics of Discrimination, $2^{\text {nd }}$ edition. Chicago: University of Chicago Press.

Bellow, A. (2003). In Praise of Nepotism: A Natural History. Westminster, MD: Doubleday Publishing.

Cleveland, William L. (2004). A History of the Modern Middle East, $3^{\text {rd }}$ edition. Boulder, Colorado: Westview Press.

Coase, R.H. (1937). The Nature of the Firm. Economica 4(16): 386-405.

Cunningham, R. and Sarayrah, Y (1993). Wasta--The Hidden Force in the Middle Eastern Society. Westport, Connecticut: Greenwood Press.

El-Ghonemy, R. M. (1998). Affluence and Poverty in the Middle East, London: Routledge Publishers

Ezzedeen, R. S. and Sweircz, P. (2001). HR System Effectiveness in the Transformative Organization: Lessons from Libancell of Lebanon. Competitiveness Review, 11(1): 34-38

Hayek, F.A. (1988). The Fatal Conceit. Chicago: University of Chicago Press.

Hutchings, K. and Weir, D. (2006).Guanxi and Wasta: A Comparison. Thunderbird International Business Review, 48(1): 141-156

Izraeli, D. (1997). Business Ethics in the Middle East. Journal of Business Ethics, 16(14): 15551560

Lipford, Jody and Bruce Yandle. (2009) The Determinants of Purposeful Volunteerism. Journal of Socio-Economics 1(38): 72-79. 
Loewe, M, and Blume, J., \& Speer, J. (2008). How Favouritism Affects the Business Climate: Empirical Evidence from Jordan. Middle East Journal, 62(2): 259-276

Meles, M. (2007). Understanding People's attitude towards the Use of Wasta, Cranfield School of Management. Master of Science Thesis

Mohamed, A. and Hamdy., H. (2008). The Stigma of Wasta: The Effect of Wasta on Perceived Competence and Morality. German University in Cairo, Working Paper Series (No 5).

Rubin, Paul H. (2002). Darwinian Politics. New Brunswick, NJ; Rutgers University Press.

Spengler, Joseph (1964). Economic Thought of Islam: Ibn Khaldun, Comparative Studies in Society and History, 6(3): 268-306

Williamson, Oliver E. (1985). The Economic Institutions of Capitalism: Firms, Markets, Rational Contracting. New York: Free Press. Cited and discussed in William F. Shughart II, The Organization of Industry, Houston, TX: Dame Publications, 1995: 54-56. 

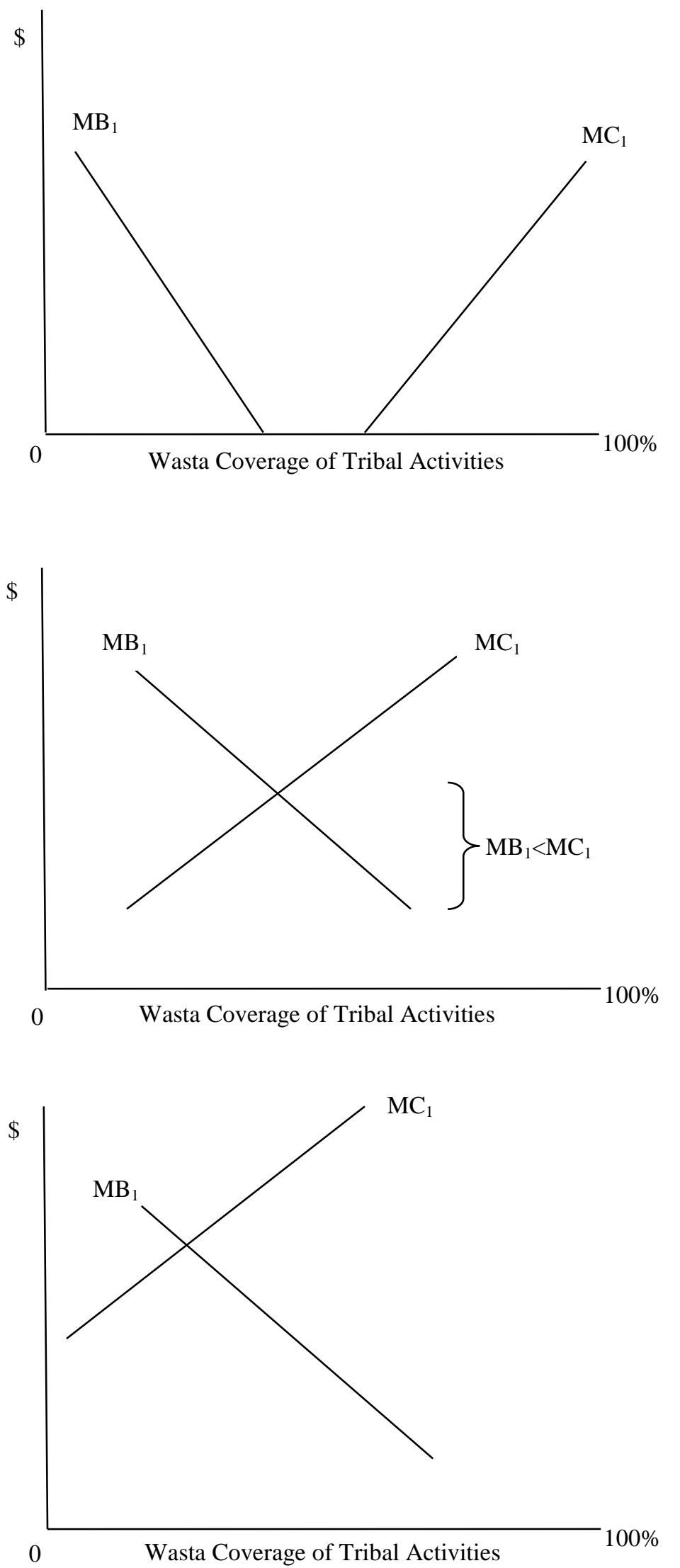

Figure 1: Marginal Benefit and Marginal Cost for using Wasta across transactions involving tribal activity.

Panel A: Initial conditions with no intersection point. $100 \%$ of tribal activities are affected by wasta.

Panel B: An intersection point exists implying a zone where the marginal benefit of wasta is less than the marginal cost of wasta.

Panel C: Given the intersection point, if wasta continues to be applied across the $100 \%$ of the wasta potential, wealth loss becomes larger. 